\title{
PONTES INTERDISCIPLINARES: INSTÂNCIAS QUE SE ABREM COMO LIGAÇÕES PARA OS DIVERSOS CAMPOS DE SABER
}

\section{The interdisciplinary bridges: instances that act as links to the various fields of knowledge}

\author{
Prof. Dr. José D’Assunção Barros \\ Docente da Graduação e Pós-Graduação em História \\ Universidade Federal Rural do Rio de Janeiro (UFRRJ) \\ ORCID: https://orcid.org/0000-0002-3974-0263 \\ Email: jose.d.assun@globomail.com
}

Recebido em: 19/06/2020

Aprovado em: 20/09/2020

\begin{abstract}
Resumo: $\mathrm{O}$ artigo propõe-se a apresentar um debate $\mathrm{e}$ delineamento sobre a Interdisciplinaridade enquanto fenômeno pertinente ao diálogo entre os diversos campos de saber, discutindo em especial as instâncias e dimensões que podem se transformar em pontes interdisciplinares entre um saber e outro, em especial a Teoria, o Método, o Discurso. Na parte inicial do artigo, empreende-se uma definição dos conceitos pertinentes ao âmbito da interdisciplinaridade, e aborda-se o aspecto histórico de qualquer campo de saber que se converte em disciplina acadêmica.

Palavras-Chave: Interdisciplinaridade; Transdisciplinaridade; Pontes interdisciplinares.
\end{abstract}

Abstract: The article proposes to present a debate and delineation about Interdisciplinarity as a phenomenon pertinent to the dialogue between the various fields of knowledge, discussing specially the instances and dimensions that can be transformed in interdisciplinary bridges between one field of knowledge and other, in particular way the Theory, the Method and the Discourse. In the initial part of the paper, it is undertaken a definition of the concepts relevant to the scope of interdisciplinarity, and the historical aspect of any field of knowledge that becomes an academic discipline is addressed.

Keywords: Interdisciplinarity; Transdisciplinarity; Interdisciplinary bridges. 


\section{Interdisciplinaridade e Disciplinas}

Em uma de suas acepções mais correntes, a Interdisciplinaridade pode ser compreendida como uma atitude, prática ou disposição que se estabelece entre os praticantes de distintos campos de saber, e que favorece o diálogo entre duas ou mais disciplinas e a ultrapassagem das perspectivas mais rígidas sobre o conhecimento que terminam por acondicionar as diferentes modalidades científicas em compartimentos estanques. Na relação interdisciplinar, dois saberes não apenas dialogam, como também permitem se renovar reciprocamente, um iluminado por outro. Para uma primeira aproximação desta ordem de riquezas e problemas que é apresentada pela perspectiva interdisciplinar, será útil que tenhamos, antes de tudo, uma clara e correta compreensão sobre o que é, afinal de contas, uma disciplina - palavra que deverá aqui ser compreendida no seu sentido de 'campo de conhecimento' ou de 'modalidade de saber' ${ }^{1}$. Ademais, será importante compreender que as disciplinas não configuram, de maneira alguma, ambientes que os seres humanos puderam simplesmente encontrar como alguém que descobre um continente novo, em uma viagem de explorações através de um vasto oceano formado por inúmeros objetos de estudo. Na verdade, o que ocorre é que os seres humanos literalmente precisaram inventar cada uma das disciplinas que hoje lhes são tão familiares neste complexo universo de saberes a partir dos quais se organiza o conhecimento humano e a prática científica. A História, Biologia, Medicina, Física, ou quaisquer outros âmbitos de pesquisa, ensino e práticas profissionais, não existiram sempre. Quando surgiram, estes campos de saber ou disciplinas tampouco nasceram prontos e acabados.

Cada disciplina, de fato, formou-se a partir de uma história particular; além disso, para continuar a existir, precisou e precisa prosseguir em um processo de permanente transformação e atualização no interior dessa história, a qual se conecta de uma maneira e de outra com as histórias de todos os demais campos disciplinares. Ademais, há inúmeras dimensões reciprocamente implicadas para a formação e continuidade de uma disciplina. Entre elas, podemos destacar a produção de instâncias teóricas e metodológicas, a constituição de uma linguagem ou de um repertório discursivo comum aos seus praticantes, a definição e constante redefinição de seus objetos de estudo, a possibilidade de identificar uma singularidade que diferencia cada disciplina de outros 
saberes, uma complexidade gradual interna que termina por gerar novas modalidades no interior da disciplina, e, por fim, o mais importante: a rede humana que constitui este ou aquele campo de saber em especial.

Outro aspecto fundamental para a compreensão das condições às quais estão sujeitas as diversas disciplinas é que elas não são compartimentos estanques, isolados uns dos outros, definidos de uma vez por todas no que concerne aos seus objetos e práticas, ainda que estas imagens sejam por vezes divulgadas ou incentivadas quando se elabora uma reflexão sobre a divisão do conhecimento humano nas suas inúmeras práticas e campos de estudo ou de pesquisa. Tampouco as disciplinas configuram campos estáticos. Ao contrário, as disciplinas transformam-se internamente, redefinemse, expandem-se ou se contraem, tendem a se tornar mais complexas na medida em que vivem a sua própria história ou se deparam com novos desafios e problemas. Além disso, conforme sustentaremos neste artigo, as disciplinas comunicam-se necessariamente entre si, deslocam-se umas em relação às outras, confrontam-se, interpenetram-se, sintonizam-se, harmonizam-se. Particularmente, para além de pensálas como organismos que se enfrentam, interagem ou disputam territórios, poderíamos pensar as disciplinas como notas musicais que repercutem umas sobre as outras, às vezes produzindo novos acordes e sempre resultando em novos afloramentos sonoros que passam a compor essa fascinante sinfonia que é o saber humano.

Metáforas à parte, o principal desafio deste artigo será o de refletir sobre as instâncias que permitem que os vários saberes dialoguem entre si, estabelecendo diálogos interdisciplinares efetivos. Neste artigo, veremos que as grandes pontes interdisciplinares - aqueles caminhos ou instâncias que se abrem ao diálogo entre duas ou mais disciplinas - são principalmente a Teoria, o Método, a possibilidade de compartilhamento de temas, o Discurso ou forma de expressão de cada saber, ou a própria rede humana que atua para a constituição de conhecimento a partir dos parâmetros de cada disciplina. Por ora, gostaríamos de lembrar ainda que os objetos de estudo e os campos temáticos de interesse das diversas disciplinas não surgiram necessariamente com elas. Os objetos de interesse científico podem migrar, em determinado momento, de um campo de saber a outro. Ou mesmo - ainda que se conservando no horizonte temático do campo de saber que originalmente os constituiu certos objetos de estudo podem passar a ser compartilhados por novos campos de saber. 
É preciso se ter consciência, ademais, de que a leitura acadêmica que hoje se faz de um universo de saberes partilhado em campos muito específicos - quase à maneira de caixas ou compartimentos no interior dos quais deveriam necessariamente se situar os intelectuais especializados - está longe de ter sempre orientado os autores e as comunidades científicas das várias épocas.

No século XVIII, por exemplo, não era incomum que os filósofos iluministas amparados por sua concepção humanista e sua perspectiva enciclopédica desenvolvessem um intenso interesse por saberes vários. Alguns deles escreveram obras ou desenvolveram pesquisas que hoje fazem parte da história de disciplinas variadas. Jean-Jacques Rousseau (1712-1778) - um dos mais notórios dos filósofos iluministas do século XVIII - escreveu livros que hoje seriam facilmente incorporáveis aos âmbitos da Educação, da História, Sociologia, Ciência Política, Economia, Linguística, Botânica ou Crítica Musical, além da própria Filosofia ${ }^{2}$. Além disso, Rousseau era literato, autor de romances e de literatura criativa em diversificados gêneros, e também músico, tendo escrito uma ópera e outras peças musicais ${ }^{3}$. A imaginação, identidade teórica e a prática autoral de filósofos humanistas como Rousseau, portanto, ainda não operava nos limites do mesmo quadro disciplinar e tendente à especialização que hoje nos é tão familiar, e que depois assumiria uma arquitetura mais definida nos meios acadêmicos e universitários. O mesmo perfil criativo e multidiversificado - ou mesmo interdisciplinar - se quisermos nos pôr à escuta das implicações de uma palavra que ainda não era utilizada na época ${ }^{4}$ - será encontrado em cada momento no qual nos propusermos a redesenhar a identidade intelectual de muitos dos outros grandes pensadores do século XVIII, como Voltaire (1694-1778), Montesquieu (1689-1755), ou David Hume (1711$1776)^{5}$, assim como também de outros homens e mulheres de saber em diversas épocas históricas. Para trás e para diante no tempo, podemos encontrar pensadores como Aristóteles ou Platão, cujas vozes nos chegam da Antiguidade, ou como Marx e Max Weber, pensadores da idade moderna, que transitaram confortavelmente pelos mais variados âmbitos de estudo.

Com isso, somos levados a reconhecer não apenas que as várias disciplinas são formações históricas, mas que mesmo o conceito de "disciplina" - ou qualquer outro que ajude a compreender melhor a diversidade do conhecimento - é também historicamente construído. Não só está sujeito a transformações históricas o próprio 
conceito de disciplina - ao lado de outras noções que ajudam a mapear o saber humano - como também a própria necessidade de criar ou operacionalizar termos e conceitos como esses deve ser compreendida historicamente. Nem todos os seres humanos, em cada uma das épocas e sociedades que já surgiram sobre a Terra, sentiram necessidade de pensar disciplinarmente. De igual maneira, mesmo nos momentos históricos onde se afirmou preponderantemente esta necessidade de pensamento disciplinar, sempre existiram resistências ao isolamento científico, particularmente através de indivíduos que manifestaram múltiplos talentos e interesses por variados campos de saber. Neste ponto, começamos a adentrar o tema da interdisciplinaridade.

\section{O vocabulário da interdisciplinaridade}

Antes de prosseguirmos, será importante lembrar alguns outros conceitos que também se sintonizam com as propostas interdisciplinares. Nos dias de hoje, não é rara a utilização da palavra 'transdisciplinaridade' para evocar uma cooperação entre várias disciplinas ou profissionais ligados às diversas áreas de saber - em um Projeto Integrado, por exemplo - mas sem que a Pesquisa ou o Projeto tenha uma disciplinabase que cumpra o papel de canalizar ou centralizar os diálogos que se dão a partir dos diversos campos de saber em questão. Pode-se ainda lembrar as noções de multi ou pluridisciplinaridade, as quais investem no estudo do mesmo objeto por diferentes disciplinas, mas sem que haja significativamente uma perspectiva de convergência quanto aos conceitos e métodos. Diante desta última perspectiva, o nível interdisciplinar propriamente dito consistiria mais precisamente em uma integração das disciplinas no nível de conceitos e métodos, aspecto, de todo modo, a ser discutido mais adiante.

Ao lado destes sentidos, também se utiliza com frequência a expressão "interdisciplinaridade" para designar uma prática que pode se estabelecer no interior de certo campo de saber com vistas às possibilidades de incorporar metodologias ou aportes teóricos oriundos de outras disciplinas, estabelecer diálogos bibliográficos com outros campos de saber, enriquecer a disciplina-base com pontos de vista oriundos de outras, e ainda abordar um certo objeto de análise comum a outros campos de saber. A interdisciplinaridade, ademais, liga-se modernamente à ideia de que a disciplina que se abre para o diálogo interdisciplinar produz, neste mesmo movimento, uma 
transformação efetiva em si ou um enriquecimento relevante em suas próprias perspectivas. Para melhor clarificar as diferenças que podem ser pensadas entre estas três palavras - interdisciplinaridade, transdisciplinaridade, multidisciplinaridade (ou a sua coirmã, a pluridisciplinaridade) - devemos atentar para os prefixos que, em cada caso, entram na sua composição. Para começar, podemos aproximar, sem maiores problemas e sem perdas significativas, as noções de pluridisciplinaridade e multidisciplinaridade. Elas incorporam radicais latinos que se referem a "muito" (multi) ou "vários" (pluri $)^{6}$.

A multidisciplinaridade, conforme este prisma, corresponderia ao reconhecimento de uma diversidade de disciplinas, e ao empenho em oferecer boas condições para a sua convivência ou mesmo cooperação ${ }^{7}$. Para além disto, autores que têm refletido sobre o que seria mais propriamente o multidisciplinar têm se dividido em apenas considerar que esta expressão se refere à mera convivência entre visões isoladas de um mesmo objeto, ou em propor a ideia de que a experiência multidisciplinar pressupõe, ou pode em certos casos pressupor, uma efetiva convergência de disciplinas que devem incidir conjuntamente sobre o mesmo objeto:

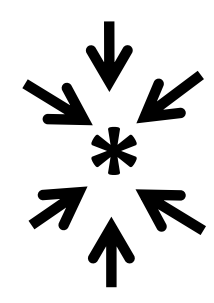

ou

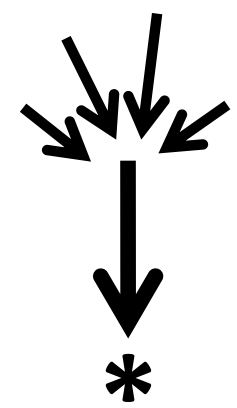

Figura 1. Duas perspectivas sobre a Multidisciplinaridade 
Nas duas representações gráficas acima, procuramos evocar estas duas diferentes interpretações ou leituras acerca do que seria a prática multidisciplinar, de modo a mostrar o sutil contraste que existe entre elas. Na primeira perspectiva de multidisciplinaridade, temos um objeto que é analisado simultaneamente por diversas disciplinas. Poderíamos ter o exemplo de um projeto escolar no qual o conjunto de professores estabeleceu o plano temático de estudar com uma mesma turma de alunos o mesmo objeto, mas em momentos diferentes e de maneiras isoladas, oferecendo em cada momento os vieses de suas próprias disciplinas sem considerar propriamente as outras. Na segunda perspectiva de multidisciplinaridade - representada pelas setas que, ao invés de convergirem cada qual para o mesmo objeto, convergem antes para um ponto comum para, a partir daí, formar-se uma nova seta - temos a ideia de que as diversas disciplinas confluem para estabelecer uma ação efetivamente integrada, sendo esta perspectiva compósita e complexa a que incide sobre o objeto. Os exemplos também se aplicam a projetos de pesquisa. Podemos ter a perspectiva na qual diversas disciplinas exploram o mesmo tema, e depois os pesquisadores apenas expõem uns para outros os resultados alcançados (1), ou a perspectiva na qual os pesquisadores se reúnem uma ou mais vezes para discutir como irão abordar conjuntamente o objeto. Com esta prática, uns dialogam com os outros. Ao final do processo, temos não apenas a mera soma de diversas perspectivas distintas e localizadas que incidiram sobre o mesmo objeto, mas sim uma situação na qual o resultado final pertence a todos (2).

Embora estas duas práticas multidisciplinares sejam essencialmente diferenciadas - uma demarcada pela justaposição de resultados, e a outra incentivada pela convergência de ações com vistas à produção de um resultado comum - ambas possuem certo patamar de similaridades. As disciplinas envolvidas, em um caso e outro, sempre conservaram muito bem guardadas as suas fronteiras. Os pesquisadores que as representam podem mesmo ter discutido e ajudado a que se produzisse um resultado integrado, no último caso, mas em nenhum momento abandonaram, deslocaram ou reconfiguraram as suas fronteiras. Vamos evocar um exemplo concreto para entender estes dois modelos de multidisciplinaridade. Digamos que o tema é a Fome, e que uma instituição de ensino ou de pesquisa decidiu investir determinada verba com vistas à produção de um livro que discutisse o assunto envolvendo as perspectivas da biologia, nutrição, história, geografia, economia e literatura. 
No primeiro modelo - o da multidisciplinaridade produzida pela justaposição de resultados obtidos por cada disciplina - o livro final poderia ser dividido em seis capítulos, nos quais os pesquisadores relacionados a cada um dos campos de saber indicados apresentassem os pontos de vista ligados ao seu próprio âmbito de pesquisa (a fome sob a perspectiva da nutrição, a fome sob a perspectiva da economia, e assim por diante). No segundo caso - o da multidisciplinaridade produzida através da confluência de saberes que produzem um único ponto de incidência sobre o objeto - o livro produzido também poderia apresentar diversos capítulos, mas não compartimentados conforme cada saber que contribuiu para o empreendimento. Digamos que a divisão temática dos capítulos fosse temporal (a fome nas diversas épocas) ou espacial (a fome nas várias partes do mundo), e que os profissionais ligados aos saberes envolvidos atuassem todos na elaboração de cada capítulo, introduzindo neles os seus pontos de vista específicos e contribuindo ativamente para uma redação em comum. Poderiam fazer isso, tal como ocorreu no primeiro modelo, sem em nenhum momento abandonar as suas próprias fronteiras disciplinares. O diálogo estabelecido teria contribuído para que se alcançasse um resultado comum. Mas pode ser que não tenha havido sequer um verdadeiro entrelaçamento ${ }^{8}$.

O exemplo do livro deve ser compreendido também como metáfora para situações diversas envolvendo o aspecto multidisciplinar: eventos reunindo pesquisadores e palestrantes de diversas áreas, montagem e funcionamento de laboratórios de pesquisa, planejamento e elaboração de currículos escolares ou relativos a qualquer outro nível de ensino, dinâmica de trabalho em instituições e conselhos de ensino ou pesquisa, fundação e constituição estrutural de institutos multidisciplinares, estabelecimento de práticas de pesquisa e de práticas de ensino, e assim por diante. A multidisciplinaridade (de um e de outro tipo) também pode se referir a um tipo de atitude individual ou coletiva no seio de cada um destes ambientes ou práticas.

Avancemos mais na discussão em torno do vocabulário da interdisciplinaridade. Com relação ao prefixo "trans", este é primordialmente de origem grega, embora depois tenha passado ao latim, e deve ser associado mais diretamente a ideias como "através de", "ultrapassagem de posições", "mudança". Podemos encontrar o movimento que pode ser associado ao prefixo "trans" em palavras como "transbordar" (ultrapassar as bordas, ou ir além das bordas). Na palavra "trânsito" podemos surpreender com bastante 
clareza essa mesma ideia de "movimento" 10 . Em "transformar" apreendemos a ideia de mudança, uma vez que aqui se tem em vista a ideia de mudança de forma ou de aspecto, ou de passagem de uma forma a outra.

A alternativa entre o "multi" ou o "trans", em vista da rápida discussão etimológica acima registrada, permite pensarmos nas expressões que agregam estes prefixos em dois caminhos distintos, os quais podem ou não ser complementares. $\mathrm{O}$ prefixo "multi" (ou o "pluri"), implica no reconhecimento de fronteiras. O "trans", entrementes, implica um projeto de "transbordamento de fronteiras", ou pelo menos a ideia de que é preciso ir além do simples "reconhecimento de fronteiras" (ou do mero respeito pelas realidades diversas que coexistem em um mesmo espaço), de modo que se almeja examinar também como as diversas realidades se interpenetram, transformamse mutuamente através de uma coexistência interativa, deixam-se afetar uma pela outra. Como um exemplo útil destes usos prefixais, pode-se evocar o reconhecimento das múltiplas identidades e realidades culturais no mundo contemporâneo, as quais são estudadas por áreas como a Antropologia, Sociologia ou História. Existem perspectivas teóricas que apresentam como principal meta o investimento no estudo da diversidade cultural. Elas também tendem a se definir diferentemente conforme utilizemos o prefixo "multi" ou "trans" antes da palavra "culturalismo". Assim, ao passo que o Multiculturalismo busca estabelecer fronteiras de reconhecimento entre as diversas culturas que coexistem em certa realidade social complexa ou em dada realidade política diversificada, o Transculturalismo procura direcionar sua ênfase de estudos para a fluidez entre estas fronteiras.

No interior deste vasto e multidiversificado campo de saber que é História, para trazer uma disciplina mais específica como exemplo, existe uma modalidade relativamente recente que é hoje denominada História Transnacional e que possui um projeto análogo. A ideia matriz deste campo histórico é ultrapassar os quadros historiográficos muito fixados pelos limites nacionais, mesmo porque certos objetos históricos não permitem isto, como por exemplo os estudos sobre os grandes impérios atlânticos do período moderno, os estudos acerca da diáspora negra ou das migrações, e ainda diversos outros temas que simplesmente não podem ser contidos pelas fronteiras nacionais e por isto precisam ser examinados a partir dos gestos epistemológicos do "cruzamento" ou da "interconexão"11. 
Com relação ao prefixo latino "inter", este se relaciona ou à ideia de uma posição intermediária (mediadora), ou à perspectiva de "reciprocidade". No primeiro caso, o prefixo tem o mesmo uso de "entre" (uma coisa que se coloca entre duas outras). Vamos encontrá-lo em palavras como "intervir"12, as quais se referem a uma mediação, ou mesmo em palavras como "interpretar", nas quais se apresenta o uso do prefixo com o sentido de "dentro"13. No segundo caso - o qual evoca a ideia de "reciprocidade" aparecem palavras como "internacional" (o espaço que se estabelece entre as nações nas suas relações recíprocas, ou o universo maior que as abrange como um todo).

Com a palavra "interdisciplinaridade", o que se tem é exatamente esta ideia decisiva de reciprocidade. $\mathrm{O}$ espaço interdisciplinar é aquele que se forma a partir das diversas disciplinas ou campos de saber que precisam não apenas se confrontar e dialogar, mas agir um sobre o outro, além de permitir que a outra disciplina haja sobre ela mesma. A interdisciplinaridade, podemos aqui inferir, não se daria "por dentro" de uma disciplina, mas sim entre duas disciplinas ou mais ${ }^{14}$. Este sentido mais geral que pode ser atribuído à interdisciplinaridade, entrementes, deixa algo no ar. Afinal, se a interdisciplinaridade é o espaço de confronto e diálogo que se produz entre as diversas disciplinas, como se dá mais especificamente esse diálogo (ou esse confronto)? Trata-se de um monólogo de mão única ou de um diálogo de via dupla? Ou essa relação entre disciplinas se constitui, de modo bem diverso, em uma espécie de entrelaçamento? Quanto às disciplinas que são levadas a estabelecer uma relação recíproca, estas apenas se demarcam umas diante das outras, cada qual vigiando atentamente o seu território, ou interagem de alguma maneira? Transformam-se ou se deformam, de uma maneira ou de outra, neste complexo processo? De onde parte, por fim, a relação interdisciplinar: de uma disciplina para as outras, ou de todas elas em conjunto, a partir de práticas e aportes que confluem para um mesmo ponto? Questões como essas, que não são resolvidas ao nível etimológico, têm dado margem a muitas discussões conceituais.

Antes de prosseguirmos, convém também ressaltar que, neste artigo, estaremos tratando de disciplinas como designação que remete aos próprios campos de saber que implicam pesquisa e produzem conhecimento, e não propriamente às disciplinas no sentido escolar e curricular. Existe uma vasta discussão mais específica sobre os currículos ao nível escolar, abordando a sua construção de uma perspectiva multi, pluri, trans ou interdisciplinar. Mas não é este, mais especificamente, o nosso escopo de 
reflexão neste artigo, e sim a relação entre as disciplinas consideradas como campos de saber (expressão que empregaremos como sinônimas) ${ }^{15}$. Queremos nos perguntar como os diversos saberes se deslocam, expandem-se ou se contraem, isolam-se ou interagem uns sobre os outros a partir de perspectivas que se opõem ao isolamento disciplinar. Queremos ainda nos perguntar e percorrer exemplos que ilustrem como, no que concerne mais especificamente a certas descobertas de pesquisas e a surpreendentes sucessos na produção de conhecimento, foi exatamente o encontro de distintos campos de saber o que permitiu avanços importantes. Para já adiantar um exemplo clássico, entre outros tantos possíveis, podemos lembrar a célebre descoberta da estrutura helicoidal do DNA, a qual se tornou possível graças à junção da perspectiva da química e da genética, e que ainda foi coroada pela colaboração final de um biólogo e de um físico (James Watson e Francis Crick); o que, aliás, valeu aos dois cientistas, no ano de 1962, o laureamento pelo prêmio Nobel de Medicina (uma quinta área disciplinar envolvida) ${ }^{16}$.

\section{As grandes pontes interdisciplinares}

Neste ponto, chegamos ao principal interesse deste artigo. Vimos nesta parte inicial que a Interdisciplinaridade é constituída por este impulso de transcender os limites de um campo de saber (de uma disciplina) e estabelecer um diálogo entre diferentes campos de saber, com vistas a alcançar a possibilidade de um conhecimento mais rico, ou atingir possibilidades que não são possíveis meramente dentro de cada compartimento disciplinar. Compreendida a importância da atitude interdisciplinar como possibilidade de renovação, podemos avançar, agora, para um novo questionamento: quando, e, sobretudo, como se dá mais propriamente o momento interdisciplinar, ou este peculiar contato interativo que se pode estabelecer entre os dois campos de saber que se colocam em diálogo? Através de que pontes, meios ou elementos de ligação dá-se o diálogo interdisciplinar? Em poucas palavras: como podem se ligar, se interpenetrar ou se entrelaçar dois campos de saber que se posicionam em uma relação interdisciplinar específica?

Partiremos da idéia básica de que, entre as diversas instâncias que constituem necessariamente uma disciplina - entre as quais a Teoria, o Método, certo padrão 
discursivo, a constituição de determinados objetos de estudo que se tornam possíveis ou preferenciais a cada campo - a própria presença de uma interdisciplinaridade mínima já é, de si mesma, também uma dimensão incontornável para cada campo de saber. De fato, por mais específico que um campo de saber se faça através da singularidade de seus objetos de estudo e dos métodos e aportes teóricos que instrumentaliza, não há de fato como uma disciplina existir sem estabelecer diálogos e oposições com outras. Já desde o momento em que surge ou se faz visível, qualquer campo de saber não pode senão se situar em uma rede de disciplinas com as quais irá se confrontar, contrastar e interagir. Ao lado disso, é preciso ainda considerar que um novo campo de saber, ao ser inserido em uma determinada rede de saberes, já a modifica necessariamente. $O$ potencial de interferência no conjunto maior de saberes, é claro, pode ser maior ou menor conforme o campo específico que se formou ou que foi inserido na rede, e certamente aqueles campos de saber que estão mais próximos se verão, mais do que outros, interferidos por uma disciplina que com eles apresenta uma maior ressonância (objetos em comum, filiações, práticas e perspectivas similares, ou outras afinidades). Parodiando a física relativística, podemos pensar na metáfora astronômica do espaço que é sempre distorcido ou interferido pela presença ou formação de um novo astro.

Ao mesmo tempo em que cada disciplina que se faz presente afeta em maior ou menor medida a rede geral de saberes, e principalmente os campos disciplinares mais próximos, é preciso ter em vista que toda disciplina científica envolve certas instâncias que são comuns a todos os campos de saber: a Teoria, a Metodologia, as especificidades de um discurso, uma rede de praticantes do campo de saber em questão, as singularidades que o definem, certo campo de interesses que podem se confrontar ou se interpenetrar com o de outras disciplinas, e assim por diante. Os métodos e teorias podem variar, os padrões discursivos entre um campo e outro podem se distinguir radicalmente, os tipos e perfis de profissionais que habitam cada campo de saber variam bastante, mas o fato é que todas as disciplinas, para existirem, precisam desenvolver suas teorias, métodos, discursos e redes de praticantes. Ao mesmo tempo, uma disciplina qualquer, à medida que se torna mais complexa, cedo começa a conformar espaços internos ao seu próprio campo de práticas e de estudos. Surgem então as diversas sub-especialidades ou âmbitos internos, ou o que podemos chamar de "campos intradisciplinares". Na Medicina surgem modalidades como a Pediatria, Cardiologia, 
Dermatologia; na Física surgem espaços intradisciplinares como a Ótica, a Mecânica, e Termodinâmica. Os campos de saber se diversificam também por dentro, e é a estes espaços internos que estaremos denominando "campos intradisciplinares". Quando um campo de saber dialoga com outro, temos a interdisciplinaridade; quando um campo de saber se diversifica por dentro temos a intradisciplinaridade.

A interdisciplinaridade entre um campo de saber e os demais que o cercam, e que com ele se interpenetram ou interagem, pode se dar através de cada uma dessas várias instâncias que necessariamente constituem cada campo de saber (teoria, método, discurso, etc). Vamos chamar aos caminhos conformados por estas instâncias, por estas porosidades ou liames a partir das quais os diálogos entre saberes podem surgir, de "pontes interdisciplinares". Uma disciplina pode dialogar com outra através de seus aportes teóricos e de certos conceitos em comum; pode incorporar, integrar ou partilhar procedimentos metodológicos que já estão bem desenvolvidos em uma disciplina irmã ou mesmo em uma vizinha distante; pode assimilar padrões e fórmulas expressivas que também constituem o discurso da outra. Diversos campos de saber, além disso, encontram consistentes caminhos interdisciplinares através das suas temáticas de estudo - ou seja, através de certas coincidências entre seus campos de interesses.

As redes de profissionais que se referem a cada campo de saber, por outro lado, podem se interpenetrar de muitas maneiras, e cooperações diversas podem ser estabelecidas. Os pesquisadores de um campo e outro podem trabalhar juntos, inspirarse mutuamente, e há ainda os casos de dupla formação - aqueles que se referem a estudiosos que se formaram ou que se estabeleceram por autodidatismo em mais de um campo de saber e que, portanto, não podem ser enquadrados única e simplesmente no interior de um só campo disciplinar. Cada um destes âmbitos - Teoria, Metodologia, Discurso, campo de interesses temáticos, bem como a comunidade de estudiosos, assim como as subdivisões intradisciplinares - pode se apresentar aos pesquisadores ligados a certo campo de saber como importantes espaços ou meios para as oportunidades interdisciplinares. Conforme veremos neste artigo, seria possível discutir, para cada uma destas pontes interdisciplinares, e para cada tipo de diálogo mais específico entre dois diferentes saberes, os seus diversos desdobramentos e implicações. Vamos começar abordando uma destas pontes interdisciplinares. O físico romeno Basarab Nicolescu (n.1942) - importante militante da moderna religação dos saberes e redator de um 
emblemático "Manifesto da Transdisciplinaridade" (1996) ${ }^{17}$ - enfatiza em suas considerações sobre o assunto principalmente a ponte interdisciplinar do Método ${ }^{18}$. Segundo suas proposições em outro texto sobre o tema (2000), o que pode conferir uma tônica interdisciplinar a qualquer trabalho é, sobretudo, a transferência de métodos de uma disciplina para outra, sendo que isto pode ocorrer em três âmbitos distintos. Vejamos esta reflexão em maior detalhe.

\section{As pontes interdisciplinares da Teoria e do Método}

Um dos mais conhecidos e percorridos caminhos interdisciplinares entre dois saberes é o das transferências, incorporações e intercâmbios de métodos. Talvez a ponte interdisciplinar do Método, como ligação entre dois campos disciplinares, só rivalize com a ponte interdisciplinar da Teoria. Consideremos que, em primeiro lugar, métodos e técnicas podem ser transferidos no nível da aplicação (1). Um relevante exemplo recente foi o da transferência de metodologias e tecnologias da Física Nuclear para a área da Medicina, o que pôde proporcionar, por exemplo, novos tratamentos e procedimentos com vistas à cura ou ao combate ao câncer ${ }^{19}$. Para acrescentar um exemplo específico do campo de saber História, podemos lembrar os métodos seriais e quantitativos que, desde fins do século XIX, já vinham sendo empregados pelos economistas com vistas aos objetos tradicionais daquela disciplina. Com a sua assimilação ativa pela historiografia, estas metodologias passaram a ser incorporadas ao programa de expansão dos interesses temáticos historiográficos para além da tradicional História Política, típica do século XIX.

Com a chamada história serial - esta nova abordagem historiográfica que surge a partir do deslocamento de métodos da Economia Histórica - desenvolve-se plenamente uma nova concepção de fonte histórica, fundada no conceito de "série" - um conjunto homogêneo de documentos ou de dados que deve ser trabalhado sistematicamente em linha, a partir da análise de conjunto, das variações e continuidades no interior da série.

O advento da abordagem serial, ultrapassando o tratamento qualitativo do documento isolado, foi saudado por muitos como uma renovação, ou mesmo como uma revolução na historiografia, e não cessou de multiplicar suas possibilidades de aplicação 
nas décadas seguintes. Não só a nascente história econômica pôde se beneficiar das metodologias seriais, mas também a história demográfica, a história local e, posteriormente, a história das mentalidades. Cada um destes subcampos ou modalidades possíveis no interior deste vasto campo de saber que é a História - um campo que, além destas modalidades citadas, apresenta muitas outras - beneficiou-se dos aportes metodológicos que já eram utilizados pelos economistas e estatísticos. Conforme se vê, inspirados nas metodologias seriais e quantitativas, os historiadores encontraram para elas campos de aplicação os mais diversos. Temos aqui o que podemos chamar de uma interdisciplinaridade criativa, que não apenas assimila práticas e métodos já empregados em outros campos, como também encontra e inventa novas possibilidades de aplicação para eles.

Avancemos na reflexão sobre a transferência interdisciplinar de metodologias. Conforme ressalta Basarab Nicolesco em seu "manifesto da transdisciplinaridade" (1996), é possível transferir métodos também no nível mais propriamente epistemológico (2). Mais do que a mera incorporação de técnicas e de um instrumental, este nível de transferências metodológicas requer revisões de perspectivas, muitas vezes em interação com a Teoria. Para prosseguir com mais alguns exemplos relacionados à disciplina História, pode-se lembrar a bem sucedida incorporação da perspectiva estruturalista, das abordagens voltadas para a análise de discurso, das análises semióticas, ou de inúmeras outras perspectivas teórico-metodológicas que já eram desde muito familiares à Linguística e à Crítica Literária. Transferidas pelos historiadores para o exame das fontes históricas, estas abordagens proporcionaram-lhes uma diversificação muito rica de metodologias de análise textual.

Neste ponto, podemos lembrar uma segunda ponte interdisciplinar que se abre ao diálogo entre dois saberes: a Teoria. Sabe-se que os diversos saberes compartilham conceitos. Considerando que os conceitos são instrumentos teóricos, pode-se dizer que o compartilhamento de conceitos em comum, entre dois ou mais campos de saber, ajudam a pavimentar esta ponte interdisciplinar importante que é a Teoria. Deixaremos para discutir os conceitos, contudo, em um tópico posterior, relacionado ao Discurso - pois ao mesmo tempo em que são instrumentos teóricos, os conceitos também são unidades de comunicação, e portanto pertinentes ao campo do Discurso - este também um universo de possibilidades que funciona como ponte interdisciplinar. 
Por outro lado, a Teoria oferece muitas outras possibilidades como ponte interdisciplinar. As grandes áreas de saber costumam compartilhar perspectivas teóricas em comum. Apenas para dar o exemplo das ciências humanas, podemos lembrar que perspectivas teóricas como a do Materialismo Histórico, do Positivismo ou do Historicismo recobre os saberes ligados às ciências humanas, da História à Sociologia, passando pela Geografia, Linguística, Antropologia, Psicologia e Economia. Não é difícil deduzir que há um grande potencial de formação de pontes interdisciplinares a partir destes e de inúmeros outros espaços teóricos que poderiam ser dados como exemplos - tanto aqueles que recobrem uma grande área de saberes, como os que se estabelecem entre duas disciplinas. Há ainda as perspectivas teóricas que se originaram em um determinado campo, mas foram utilizadas com sucesso em outros. A perspectiva da polifonia - originária da Música - estendeu-se por exemplo para a Linguística, possibilitando enxergar certos tipos de discursos como entremeados discursivos constituídos por muitas vozes, como ocorre com as composições musicais polifônicas. O mesmo modo de ver, entrementes, em outro momento passou a beneficiar a História e hoje falamos, por exemplo, em fontes polifônicas, para nos referirmos a tipos de documentação nos quais várias vozes parecem competir em um mesmo espaço discursivo, tal como ocorre nos jornais e nos processos criminais. A Teoria, certamente, é uma ponte interdisciplinar crucial que pode se estabelecer entre dois diferentes saberes, e mais adiante veremos que esse aspecto também ocorre através dos conceitos.

\section{Formação de novos espaços intradisciplinares}

A terceira possibilidade de uso da ponte metodológica sinaliza para a geração de novas disciplinas, ou de novos campos intradisciplinares. A Astrofísica, por exemplo já de si mesmo uma interdisciplina - beneficiou-se da transferência de metodologias pertinentes à física de partículas. Isso proporcionou o franco desenvolvimento de uma surpreendente cosmologia quântica. Podemos lembrar, mais uma vez, um caso referente à História. A transferência, para este campo, de métodos e de procedimentos diversos oriundos da Geografia, bem como também de suas contribuições teóricas, terminou por gerar a Geo-História. Um campo intradisciplinar como este, aliás, já é de si mesmo uma grande e relevante ponte interdisciplinar: um espaço comum diante do qual e dentro do 
qual podem circular os estudiosos ligados a um e outro destes campos originais de saber (a História e a Geografia). A Geo-História nos oferece um exemplo autoexplicativo que aflorou a partir da quinta década do século XX, particularmente sob a contribuição original do historiador francês Fernand Braudel (1902-1985) com sua célebre obra sobre O Mediterrâneo nos Tempos de Philippe II (1949). Mais tarde, viriam outros campos intradisciplinares similares, como a História Ambiental. Esta pode ser vista como uma área de saber que propõe estender uma ponte entre a História Natural e a História Social. Deste modo, estabelece-se aqui um diálogo entre a História, a Geografia, e as diversas ciências da vida, como a Biologia (incluindo campos intradisciplinares como a Zoologia, a Botânica, a Ecologia), sem esquecer os campos de saber relacionados ao estudo do meio, como a Geologia, a Oceanografia e a Meteorologia. Todo esse caudal interdisciplinar conflui para possibilitar a formação e reatualização de um campo novo que vem sendo chamado de História Ambiental ${ }^{20}$.

Tudo o que se disse atrás acerca da ponte interdisciplinar do Método - mais particularmente seus deslocamentos possíveis nos níveis da aplicação, epistemologia e geração de novas disciplinas e espaços intradisciplinares - poderia ser dito igualmente para a ponte interdisciplinar da Teoria. As ciências humanas, obviamente, sempre compartilharam muitas perspectivas teóricas entre si, e não é nada raro que um viés teórico desenvolvido originalmente em uma delas se expanda para as outras. Ademais, como veremos mais adiante, a ponte interdisciplinar da Teoria também oferece a possibilidade de transferências conceituais, isto é, as diversas oportunidades de incorporação e adaptação de conceitos de uma disciplina em outra.

\section{Discurso e Conceito como ponte interdisciplinar}

Com relação à ponte interdisciplinar do Discurso, os diversos campos de saber também travam contínuos diálogos: uns assimilam vocabulário originário de outros; às vezes inventam-se termos e conceitos no entrecruzamento de campos distintos. Da mesma forma, os modos de expressão provenientes ou comuns a um campo podem influenciar significativamente o outro. 
Quantos conceitos originaram-se em um campo e foram recebidos no repertório vocabular de outro? Um exemplo típico está no conceito de "crise": originário da medicina, na qual designava e ainda designa diversos processos corporais e vitais como a falência, sobrecarga ou mau-funcionamento de órgãos ou de sistemas vários. $O$ conceito migrou, nas primeiras décadas do século $\mathrm{XX}$, para campos como a economia, ciência política e história, e hoje faz parte do vocabulário comum que se vê nos noticiários todos os dias. Também conceitos como o de "segregação", oriundo da botânica, foram recebidos em certo momento pelas ciências humanas, de modo a designar fenômenos como a segregação social.

Além disto, há também conceitos e termos que já nascem mais propriamente como "conceitos transdisciplinares" 21 . Alguns deles têm origens em saberes ou perspectivas que já são, por si mesmos, tendentes à transdisciplinaridade, no sentido de que são pouco localizáveis no interior das fronteiras de um único saber mais convencional. Emílio Roger Ciurana, que atenta para este aspecto, dá como exemplos destes saberes transdisciplinares, entre outros, a "teoria dos sistemas" e a "teoria da informação". Da mesma forma, entre os conceitos que já nasceram tendentes à transdisciplinaridade, indica certos conceitos típicos da linguística saussureana, como “código", “mensagem”, e assim por diante ${ }^{22}$.

A reapropriação conceitual entre disciplinas é bastante comum. Para evocar o exemplo da disciplina História, é oportuno considerar que este é um campo de saber que não cessa de renovar e enriquecer o seu próprio vocabulário a partir do vocabulário conceitual trazido de outras disciplinas. Ao lado disso, considerando que entre os objetivos da História inclui-se a produção de textos expressivos - inclusive dotados de uma dimensão estética e literária (o texto final do historiador que pretende apresentar os resultados finais da pesquisa em forma de uma narrativa crítica e analítica) - é evidente que campos como o da Literatura podem e devem contribuir diretamente para uma renovação do discurso da História. Agora já não falamos apenas da incorporação de conceitos, mas da assimilação de novos estilos e recursos expressivos. O historiador, enfim, produz um gênero literário específico que é o texto historiográfico. Por isso, a interdisciplinaridade com os recursos expressivos é uma necessidade para o desenvolvimento da História em novos níveis de expressão. O mesmo se pode dizer de boa parte dos saberes ligados às ciências humanas e sociais. 


\section{Temáticas compartilhadas}

Chegamos às pontes interdisciplinares que se estabelecem a partir das temáticas de estudo e de investigação. Não é nenhuma novidade que um determinado campo de saber pode se ligar a inúmeras outras disciplinas através de interesses temáticos em comum. O caso da História, mais uma vez, é exemplar. Tudo, afinal, tem uma história. Além de partilhar interesses de estudo com outras ciências humanas - uma vez que os historiadores estudam temas que também são habitualmente caros aos sociólogos, antropólogos, geógrafos, psicólogos e linguistas - não há limite para os aspectos que podem ser examinados de uma certa perspectiva historiográfica. Os próprios campos de saber, conforme já vimos, têm também, cada um deles, a sua própria história, e podem por isso ser examinados pelos historiadores que se dedicam à História das Ciências. Fenômenos físicos, naturais, biológicos - e as relações que os seres humanos estabelecem com eles - podem se redesenhar como objetos para estudos historiográficos específicos. Há por exemplo uma História do Clima, uma História da Alimentação, uma História da Doença ${ }^{23}$.

Muitos outros exemplos poderiam ser dados para exempificar as pontes interdisciplinares que se formam a partir de objetos e temas compartilhados. A quem pertence o átomo? Aos físicos? Aos químicos? Entre que saberes transita esta realidade mínima que já não é mínima, e que um dia pertenceu à especulação filosófica? E as células, como se compartilham entre os biólogos, botânicos, médicos de diversas especialidades? A quem pertence o interesse pelos chamados loucos? Psicólogos, psiquiatras, sociólogos, antropólogos, historiadores? Poetas? Não serão as cidades como no mundo já os são - espaços intensos de trocas e compartilhamentos, já que por elas se interessam urbanistas, sociólogos, antropólogos, historiadores, e ainda os psicólogos que estudam os modelos de comportamentos dos seres humanos que nelas habitam?

Todos esses campos temáticos - o átomo, a célula, os loucos e as cidades - bem como inúmeros outros, podem nos oferecer pontes interdisciplinares que obrigam os saberes a, mais uma vez, se encontrarem muito além dos horizontes que os definem. Seria possível a História e a Geografia estudarem seriamente quaisquer dos seus 
inúmeros objetos de interesse sem se esbarrarem uma na outra, ou sem se enlaçarem amistosamente?

\section{A rede humana e autoral entre as disciplinas}

A rede humana e a configuração multiautoral de um campo, ou de vários campos em interdisciplinaridades cruzadas, podem se oferecer como pontes interdisciplinares de muitos modos. Quero lembrar aqui, principalmente, três destas pontes interdisciplinares que se estendem através da rede humana ou autoral: [1] o pesquisador dotado de formação ou informação interdisciplinar; [2] as equipes interdisciplinares de pesquisadores; [3] o recuo aos autores clássicos que ainda não atuavam, na época de enunciação de suas obras, no interior de uma conformação disciplinar demasiado rígida.

Antes de prosseguir, registro desde já um aparte: quando falo de pesquisadores, poderia também estar falando de professores, trabalhadores, cientistas, artistas, bem como de representantes das mais diversas práticas. Falar das práticas e diálogos interdisciplines que são estabelecidos e postos em movimento por pesquisadores - isto é. pelos pensadores que atuam na produção do saber dito científico - é só uma questão apropriada para exemplificar e facilitar um discurso. De fato, tudo o que for dito aqui, rigorosamente falando, não precisa se restringir apenas à interdisciplinaridade científica: pode se estender às interdisciplinaridades pedagógica, escolar ou prática, ou inclusive, ainda, às interdisciplinaridades artísticas, seja entre grandes campos de expressão artística - como as Artes Visuais, a Música e a Literatura - ou no interior de um mesmo grupo (por exemplo, entre a pintura e a escultura, que compartilham um espaço comum no interior das artes visuais). Vou me concentrar, entretanto, em exemplos mais específicos relacionados à interdisciplinaridade científica.

Quando pensamos em discutir o papel, como pontes interdisciplinares importantes, dos próprios seres humanos que produzem conhecimento - eles mesmos, como indivíduos concretos e contextualizados - vêm-nos logo à mente aqueles indivíduos de diversificada formação ou de elevada informação interdisciplinar. Lá no extremo mais raro do espectro, temos os polímatas, que são os indivíduos que se sobressaem com extraordinário destaque em diversas áreas. Podem ter obtido 
capacitação formal em várias áreas, ou ter conquistado esta multicapacitação de modo autodidata ou mesmo através da experiência. Em alguns casos, para o qual podem ser citados alguns exemplos históricos muito conhecidos, possuem um surpreendente feixe de habilidades que neles parecem tão naturais que se torna difícil explicá-las.

É comum lembrarmos os nomes de Leonardo da Vinci (1452-1519), Aristóteles (384-322 a.C) ou Leibniz (1646-1716). Mas impressionam mais ainda os polímatas que já vivem ou viveram nos tempos de fragmentação disciplinar do período contemporâneo, sendo oportuno relevar que, na Itália renascentista de Leonardo da Vinci, ou na Grécia clássica de Aristóteles, vigorava um modelo de Paideia (de formação humanista universal) que estimulava o indivíduo educado a se familiarizar efetivamente com diversos saberes. Já mostramos que, a partir do século XIX, passa a vigorar um modelo de parcelarização dos saberes que autoriza e mesmo motiva o orgulho monodisciplinar - o orgulho de cada um ficar no seu pequeno canteiro de conhecimento, onde cultivará sempre as mesmas rosas através das águas da especialidade.

$\mathrm{Na}$ verdade, não precisamos do polímata para termos o 'indivíduo interdisciplinar' (não nos referimos aqui, neste momento, ao indivíduo 'animado da atitude interdisciplinar', mas ao indivíduo que tem mesmo mais de uma formação). Basta ter uma dupla formação, o que não é tão incomum - mesmo nesse mundo tendente à fragmentação dos saberes - que já se forma um passim de interdisciplinaridade através de um mesmo indivíduo. Por outro lado, quero dizer que, para pensarmos na rede humana como ponte interdisciplinar, não precisamos nem mesmo os indivíduos de dupla ou múltipla formação. Existe o recurso das chamadas equipes interdisciplinares. A cooperação entre profissionais ligados a diferentes saberes é suficiente para que se faça da rede humana uma ponte interdisciplinar. Por fim, quero mencionar uma terceira possibilidade de estimula interdisciplinar através da rede humana - neste caso da rede autoral - lembrando a proposta de Juan Jose Castillo em seu instigante artigo sobre "O Paradigma Perdido da Interdisciplinaridade” (1987):

Minha proposta, buscando o paradigma perdido da interdisciplinaridade, é retornar a esses clássicos ${ }^{24}$, que são nosso tronco comum, e também nossas raízes, sem as limitações dos encastelamentos atuais, tanto profissionais, como disciplinares ou científicos ${ }^{25}$ 
De fato, quando voltamos a um clássico como Karl Marx (talvez não seja o melhor exemplo, se considerarmos que Marx era, de certo modo, um polímata), temos alguma dificuldade em escolher para ele uma única localização no quadro geral dos saberes. Seria melhor defini-lo como filósofo, economista, sociólogo, historiador, cientista político, ou talvez militante? O paradigma do Materialismo Histórico, que se formou em meados do século XIX e passou a ser compartilhado pelas diversas ciências humanas - rendendo frutos principalmente no século $\mathrm{XX}-$ foi construído interdisciplinarmente. Não é preciso lembrar que Marx, tendo uma formação filosófica inicial, precisou estudar profundamente toda a produção das ciências econômicas já disponível em sua época, para enfrentar o desafio de escrever O Capital (1867).

A rigor, se considerarmos alguns dos economistas ingleses nos quais Marx se baseou para a configuração crítica de seu próprio pensamento econômico - tais como Adam Smith e Ricardo - nem podemos dizer que eles já eram diretamente rotuláveis como economistas, pois são tanto pioneiros como anteriores, propriamente dito, à formação deste campo disciplinar que é a Economia. As ciências econômicas os assimilam, como não poderia deixar de ser, aos seus quadros disciplinares. Mas Adam Smith (1723-1790) tanto escreveu obras que fundam a Economia Política, como produziu trabalhos em outros campos, como a Filosofia Moral ${ }^{26}$. Não fez isso porque era um polímata, ou nem mesmo porque tinha uma dupla formação ${ }^{27}$, mas simplesmente porque sua atuação autoral precede de fato à formação de um campo disciplinar, rigorosamente falando, como o da Economia Política.

Algo similar também ocorre, por exemplo, com Philippe Pinel (1745-1826), médico francês que viveu o período da Revolução Francesa. Pinel é muito habitualmente evocado como um dos fundadores da Psiquiatria, e por isso inserido, pela história da ciência, no interior deste campo. Na verdade, era um médico propondo novas categorias para a classificação de distúrbios mentais ${ }^{28}$. Mais tarde - por conta de certos episódios da Revolução Francesa nos quais Pinel ordena a libertação de alienados mentais que estavam presos a correntes de ferro no Manicômio de Bicêtre, situado nos arredores de Paris - passaria também a ser evocado como um antecipador distante do emblemático movimento anti-manicomial que ocorreu nos anos $1970^{29}$. Deste modo, a referência dissonante ao mesmo sujeito de conhecimento terminou por ser convocada, 
em momentos distintos, para a historiografia de origem de duas posições epistemológicas antagônicas: a psiquiatria e a antipsiquiatria.

Quando retornamos a alguns dos clássicos, podemos voltar a um ponto onde a disciplina ainda não se tinha formado - ou, ao menos, a um ponto no qual a disciplina ainda não era tão rígida nos seus limites, na definição dos seus objetos, na hiperespecialização dos seus praticantes. Há clássicos, como o filósofo grego Aristóteles (384-322 a.c), cujas obras multidiversificadas praticamente constituem entroncamentos de muitos saberes. É possível encontrar, também nos clássicos (ou nos exploradores pioneiros, podemos chamá-los assim), posições que posteriormente deram origem mesmo a epistemologias antagônicas.

O autor clássico também pode ter se constituído, ele mesmo, em um espaço de transição entre duas disciplinas, como veremos mais adiante ter sido o caso de Max Weber (1864-1920), que hoje é classificado disciplinarmente como sociólogo, mas que só assumiu essa identidade disciplinar em um momento mais tardio de sua trajetória autoral. Muitas vezes, o retorno ao clássico é saudável não apenas por causa de sua contribuição específica - a qual, de fato, também é importante - mas também porque a sua obra nos habitua à interdisciplinaridade, uma vez que permite que nos situemos em um momento anterior a certos encastelamentos disciplinares e intradisciplinares que ocorreram na história de certos campos de saber. Esta é mais uma das razões que fazem dos clássicos uma fonte incontornável de aprendizado: não apenas são fundamentais para a disciplina que os elege como referência importante dentro do campo, como também ensinam a transitar entre as disciplinas. Os clássicos, neste sentido, apresentamse como significativas pontes interdisciplinares. Eles nos situam em um patamar do qual podemos olhar para as coisas de um ponto de vista fora da caixa.

\section{A inspiração da Arte}

Se alguns dos clássicos podem ser inspiradores pela sua anterioridade em relação à rigidez disciplinar, pela sua maior criatividade com relação a percorrer - já no período contemporâneo - as pontes interdisciplinares, e pela sua maior audácia em relação a novas formas de pensar (que depois outros passam a seguir), há uma outra inspiração importante que deve ser considerada para a interdisciplinaridade científica: a Arte. 
Ainda mais que os cientistas, os artistas são mais audaciosos na exploração interdisciplinar.

Em períodos mais recuados, como no Renascimento Italiano, ouvimos falar de grandes artistas que não se limitavam a uma única modalidade de expressão artística. Michelangelo e Leonardo da Vinci eram pintores, escultores, arquitetos, poetas. Este último foi também cientista, inventor, engenheiro, botânico, anatomista, geógrafo, e, muitos não sabem, também músico. No caso de Leonardo da Vinci, já temos novamente a figura do polímata, e talvez mesmo o indivíduo dotado da maior diversidade de talentos, entre os nomes que ficaram registrados na história. Mas mesmo desconsiderando a figura sem precedentes de Leonardo da Vinci, e ainda de Michelangelo, que também se destacou em talentos diversos, devemos lembrar que não era nada incomum o modelo do artista que circula nas diversas esferas de expressão artística, ou ao menos no interior de uma esfera mais específica como as diversas artes visuais.

Neste último caso, não era nada incomum que o mesmo artista se dedicasse, à pintura e à escultura, e também a outras artes visuais como a cerâmica, desenho, gravura e arquitetura. Nos tempos mais recentes, incorporaram-se ao universo das artes visuais a fotografia, o vídeo, e mesmo, em certo sentido, o Cinema - que de todo modo já constitui a sua própria esfera. Os artistas visuais continuam, como outrora ocorreu, dedicando-se ao trabalho em diferentes técnicas e processos, embora também não seja incomum encontrarmos artistas que se dediquem somente à pintura, por exemplo. Para a nossa discussão sobre a interdisciplinaridade, o que quero ressaltar é que a pintura e a escultura implicam técnicas muito diversas, e mobilizam também diferentes visões de mundo, assim como a cerâmica e o desenho, e mais ainda outras possibilidades que se tornaram possíveis com a tecnologia dos dois séculos recentes, como a fotografia e o vídeo. Não obstante, os artistas têm, mais do que os cientistas de diversos tipos, uma maior ousadia para ultrapassar a sua especialidade artística original, no caso em que possuem uma com a qual mais se identificam ou a que mais se dedicam. Sustento que, na Arte, encontramos uma atitude interdisciplinar mais intensa.

O modelo do uomo universalis era muito difundido como um ideal renascentista, realizando-se em nomes para além dos polímatas mais excepcionais que já mencionamos. Podem ser citados artistas como Leon Battista Alberti (1404-1472) - 
pintor, escultor, arquiteto, urbanista e músico. Também o famoso pintor Rafael Sanzio (1483-1520) foi arquiteto, designer de objetos e cenógrafo - além de pesquisador da antiguidade clássica e antecipador dos profissionais dedicados à preservação do patrimônio artístico. Podemos encontrar nomes de menor destaque, como o de El Greco (1541-1614), também pintor, escultor e arquiteto. E, o quanto quisermos, podemos seguir encontrando novos exemplos, pois era comum aos artistas visuais renascentistas circularem ao menos nas modalidades situadas no âmbito das Artes Visuais, por mais distintas que suas técnicas e materiais de trabalho sejam.

Curiosamente, foi na modernidade oitocentista - a mesma na qual já vimos se afirmar uma maior demarcação disciplinar - que começam a aparecer mais os artistas especializados em uma única modalidade expressiva, como a pintura e a escultura. Mas, de todo modo, os artistas - mesmo quando dedicados a uma única arte ou técnica sempre costumaram estar atentos às outras modalidades do seu campo, ou às outras formas de expressão artísticas. Os pintores românticos estavam particularmente atentos à Literatura; além disso, havia a concepção romântica da "obra de arte total", encaminhada pelos dramas musicais wagnerianos ${ }^{30}$. Já os pintores cubistas e expressionistas do período moderno estiveram muito atentos à Música. O pintor russoalemão Wassilly Kandinsky (1866-1944), por exemplo, costumava estender uma imaginação musical sobre a sua arte pictórica, e chamava aos seus quadros de "composições", como fazem os músicos em relação às peças musicais por eles criadas. Também chamou a algumas de suas obras, produzidas mais espontaneamente, de "improvisações" - outra alusão a um procedimento musical.

Foi a possibilidade de imaginar e sentir musicalmente o seu universo pictórico o que permitiu que Kandinsky criasse um estilo inteiramente inovador no seio do expressionismo abstrato alemão ${ }^{31}$. As cores e formas com as quais Kandinsky cria a suas composições, em boa parte delas evitando os contornos geométricos mais tradicionais, fluem como sonoridades musicais que dialogam harmônica e polifonicamente. De fato, não poderia haver para a pintura abstrata de Kandinsky e de outros expressionistas abstratos uma afinidade eletiva mais adequada do que a da Música - ela mesma a mais abstrata das artes e a grande configuradora de uma linguagem própria que já se mostra, de saída, liberta da necessidade de representar o mundo exterior, a não ser nos gêneros musicais descritivos (os poemas sinfônicos) ou 
em gêneros vocais como a canção ou a ópera, nos quais a Música se alia, para este fím, à Poesia.

Essa propriedade única da linguagem musical, que a tornou particularmente inspiradora e relevante para a interdisciplinaridade artística com a pintura abstrata, foi muito bem expressa pelo antropólogo belga Claude Lévi-Strauss (1908-2009), em uma das mais singulares de suas obras (O Cru e o Cozido). Nesta obra sobre as mitologias indígenas, Lévi-Strauss ousa estender uma imaginação musical sobre a Antropologia (ao mesmo tempo em que retribui com uma imaginação antropológica dirigida para a compreensão da música), e considera que, dentre todas as linguagens, a Música "é a única que reúne as características contraditórias de ser ao mesmo tempo inteligível e intraduzível"32.

Pois é esta dupla propriedade da linguagem musical, de ser a um só tempo inteligível e intraduzível, que Kandinsky procura trazer para as suas realizações pictóricas. Suas obras são pensadas como pinturas musicais, ou composições pictóricas $^{33}$. Sem ter ousado explorar mais criativamente a interdisciplinaridade entre Pintura e Música, Kandinsky não teria chegado a esta realização tão singular no universo das criações expressionistas. Além disto, o pintor correspondeu-se durante cinco anos com o músico expressionista Arnold Schoenberg (1874-1951) - introdutor de uma nova linguagem no interior da música, o atonalismo, e posteriormente de um sistema musical inovador que ficou conhecido como Dodecafonismo.

Arnold Schoenberg, sintomaticamente, também era pintor, embora em suas telas, bem menos conhecidas do que suas realizações musicais, tenha optado por um expressionismo figurativo, à maneira de Oskar Kokoschka (1886-1980). Schoenberg também interagiu amplamente com a poesia e o teatro expressionista. Em muitas das cartas trocadas entre Kandinsky e Schoenberg, são discutidos intensamente os diálogos possíveis entre as duas artes ${ }^{34}$.

A inspiração na atitude artística de explorar o encontro entre modalidades tão distintas como a Pintura e a Música, renovando uma e outra, poderia beneficiar a interdisciplinaridade científica. Seria possível imaginar antropologicamente a História? Não faltaram realizações neste sentido. Ou que tal pensar historiograficamente a Geografia? Ou, ainda, geograficizar a Linguística? Por que não pensar musicalmente a Física? 
Outro exemplo de atitude interdisciplinar na arte - ou mesmo transdisciplinar, já que propões transcender as modalidades artísticas tradicionais e terminou por constituir uma nova interdisciplina ou interarte - foi o da Colagem. A nova técnica passou a ser utilizada ainda na primeira metade do século XX por artistas cubistas como Pablo Picasso (1881-1973) e Georges Braque (1882-1963), e também pelo pintor fauvista Henri Matisse (1869-1954). A colagem era já o primeiro passo de uma pintura que queria ultrapassar os limites de uma pintura elaborada em uma superfície de duas dimensões. A técnica consiste em colar pedaços de papel colorido ou desenhado, ou outras texturas, na tradicional superfície plana de uma tela.

A Colagem não poderia ser imaginada se não se ultrapassasse o conceito planar de pintura. Para ser idealizada e realizada, foi preciso uma atitude interdisciplinar ou interartística - uma transcendência de duas modalidades já tradicionais nas artes visuais: a pintura e a escultura. A colagem está nesse encontro entre duas modalidades distintas, assim como também diversas outras práticas e realizações posteriores, como os contrarelevos de Rodchenko (1891-1956) - que também constituem objetos intermediários entre a pintura e a escultura - ou ainda as arquiteturas suprematistas de Malevich (18981935), que entrelaçam as modalidades da escultura e arquitetura ${ }^{35}$. No Brasil dos anos 1960, a transcendência da pintura na direção do espaço também foi realizada por artistas como Lygia Clarke (1920-1988) e Helio Oiticica (1937-1980). Este último, depois de realizações com a pintura concreta, começou por construir pinturas de dupla face que tinham de ser observados pelo espectador pelos dois lados e por todos os ângulos; depois, chegou aos objetos suspensos no teto, até conceber finalmente às instalações que tinham de ser penetradas pelos observadores, em um gênero que já era uma interarte que unia pintura, escultura e arquitetura e mesmo outros campos de expressões $\operatorname{artísticas~}^{36}$.

Com todos estes exemplos, e muitos outros que poderiam ser dados, quero sinalizar para a ocorrência mais habitual, entre os artistas, de uma atitude interdisciplinar ou transdisciplinar. $\mathrm{Na}$ arte, os limites são atravessados com maior facilidade. Também ocorrem os diálogos da Arte com disciplinas exteriores ao mundo artístico, como foi o caso da Arte Conceitual, no qual artistas como Josep Kosuth (n.1945) estabeleceram um diálogo bastante singular entre Arte e Filosofia ${ }^{37}$. 
Além dos exemplos até aqui evocados, algumas das diversas formas de arte pressupõem necessariamente $\mathrm{o}$ trabalho interdisciplinar entre artistas ligados a diferentes formas de expressão. É o caso de gêneros musicais específicos, como a ópera (espetáculo teatral e musical que dramatiza enredos muitas vezes inspirados na Literatura), e é o caso, mais ainda, do Cinema - a arte que reúne dentro de si todas as outras, embora constituindo uma linguagem própria.

O Cinema é interdisciplinar - e interartístico - por excelência. Dificilmente poderia ser de outra maneira. Ainda que excepcionalmente tenha contado com cineastas interdisciplinares - como o multi-artista britânico Charles Chaplin (1889-1977), que foi diretor, roteirista, ator, músico e produtor de suas realizações - o modelo essencial do Cinema é certamente o da equipe interdisciplinar. Enquanto um laboratório de Microbiologia costuma contar com uma equipe formada exclusivamente por microbiologistas, já o set cinematográfico congrega necessariamente uma grande equipe formada por artistas, profissionais e técnicos ligados ás mais diversas especialidades, sem contar o trabalho prévio realizado pelo roteirista e o trabalho posterior do montador e de outros profissionais que trabalham na edição da obra fílmica. No set, teremos também a presença de determinados campos artísticos e técnicos criados ou aperfeiçoados especialmente para o cinema, como a Fotografia ${ }^{38}$. A isso tudo se junta a Cenografia, a Música e outros campos artísticos já tradicionais, quando não a Literatura, nos casos em que o roteiro do filme é extraído de alguma obra literária. Se o filme é histórico ou biográfico, também incluirá o trabalho de pesquisadores. Por fim, os atores e atrizes, e toda a equipe de diferentes profissionais que se responsabilizam pelas suas imagens, indumentária, maquiagem e tantas outras coisas mais.

Interdisciplinar, o Cinema é quase sempre obra coletiva, ainda que se possa pensar em um filme construído com "uma câmera na mão e uma ideia na cabeça" "39. Em contrapartida, basta um autor e uma caneta na mão para se escrever um livro, seja este um romance ou um ensaio antropológico. A esta experiência solitária contrapõe-se o Cinema. A Ciência também deveria ser (e na verdade é) uma imensa produção coletiva, sendo que cada uma de suas realizações específicas traz as marcas indeléveis desta coletivização, e também dos diálogos interdisciplinares que as tornaram possíveis. No entanto, nem todos os cientistas parecem ter a devida consciência disto. $\mathrm{Ou}$, ao menos, parecem ter menos consciência da rede coletiva e interdisciplinar que os envolve do que 
os artistas - músicos acostumados a tocar juntos as obras de outros ou a compor trilhas para o cinema, pintores que se citam uns aos outros através das releituras de grandes obras de arte, coreógrafos que se juntam aos pintores para compor o cenário e o movimento de um espetáculo dançante de teatro. Cineastas, talvez, que dão vida e movimento ao pequeno mundo solitariamente imaginado por um romancista, ou poetas que são convocados para acrescentar letra a uma bela melodia. Criadores de instrumentos musicais, quem sabe, que lidam atentamente com as séries harmônicas e proporções descobertas pelos matemáticos, e ainda os arquitetos que procuram apaixonadamente conciliar as preocupações estéticas das artes visuais com a praticidade dos engenheiros A Arte não poderia ajudar a Ciência a ter maior consciência de sua interdisciplinaridade? Com esta questão, encerramos esta reflexão sobre as pontes interdisciplinares que podem ligar dois ou mais diferentes campos de saber.

\section{Referências}

BRAUDEL, Fernand. O Mediterrâneo e o Mundo Mediterrânico. São Paulo: Martins Fontes, 1984 [original: 1949, revisto em 1965].

CASSIRER, Ernst. Le problème Jean-jacques Rousseau, Paris: Hachette Pluriel, 2012.

CASTILLO, J. J. El paradigma perdido de la interdisciplinariedad: volver a los clássicos. Política y Sociedad, n²6, 1987, p.143-155.

CASTRO, Josué de. Geografia da Fome. Rio de Janeiro: Antares, 1983 [original: 1946].

CIURANA, E. R. "Complexidade: elementos para uma definição" In: CARVALHO e MENDONÇA (orgs.). Ensaios de complexidade 2. Porto Alegre: Sulina, 2003, p. 48-63.

FREITAS, Inês A. de. História Ambiental e Geografia Física: Natureza e Cultura em Interconexão. Geo UERJ, ano 9, n¹7, vol. 2, 2007, p.20-33.

JAPIASSU, Hilton. Interdisciplinaridade e Patologia do Saber. Rio de Janeiro: Imago, 1976. 
KANDINSKY, W. Do Espiritual em Arte - e na pintura em particular. São Paulo: Martins Fontes, 1996 [original: 1912].

KLEIN, Julie Thompson. Interdisciplinarity - History, Theory \& Practice. Detroit: Wayne State University, 1990.

KLEIN, Julie Thompson. Crossing Boundaries: Knowledge, Disciplinarities and Interdisciplinarities. Charlottesville: University Press of Virginia, 1996.

LE ROY LADURIE, Emmanuel. Histoire du climat. Paris: Flammarion, 1967.

LÉVI-STRAUSS. O Cru e o Cozido (Mitológicas, I). Rio de Janeiro: Cosac \& Naify, 2010 [original: 1964].

MARX, Karl, "O fetichismo da mercadoria". In: O Capital: crítica da economia política. Rio de Janeiro: Civilização Brasileira, 1971, p. 64-112 [orig: 1867].

NASH, Robert. American Environmental History. A New Teaching Frontier. Pacific Historical Review, vol.41, p.362-377, 1972.

NAVEH, Z. What is holistic landscape ecology. A conceptual introduction. Landscape and Urban Planning. vol.50, p.7-26, 2000.

NICOLESCU, Basarab. Manifesto da Transdisciplinaridade. São Paulo: Trion, 1999 [original: 1996].

NICOLESCU, Basarab. Um novo tipo de conhecimento: transdisciplinaridade. In: Educação e transdisciplinaridade. Brasília: UNESCO, 2000.

PINEL, Philippe (1801). Traité médico-philosophique sur l'aliénation mentale ou la manie. Paris: Richard, Caille \& Ravier.

POMBO, O. Epistemologia da Transdisciplinaridade. Ideação, vol.10, n 1, 2008, p.9-40.

POMBO, Olga; GUIMARÃES, Henrique Manuel; LEVY, Teresa (orgs). Interdisciplinaridade: Antologia. Porto: Campo das Letras, 2006.

SABATIER, François. Mirois de la Musique. Paris: Fayard, 1998.

SEIGEL, M. "Beyond Compare: Comparative Method after the Transnational Turn”. Radical History Review, nº.91, Winter 2005, p.62-90. 
STRAUSS, John. Rousseau: Musician. The Musical Quarterly, Vol. LXIV, Issue 4, October 1978, Pages 474-482, https://doi.org/10.1093/mq/LXIV.4.474.

SUBRAHMANYAM, S. Connected History: Explorations in Connected History - Mughals and Franks. Delhi: Oxford University Press, 2004.

WORSTER, D. "Doing Environmental History" In: WORSTER, D (org,). The Ends of the Earth: perspectives on Modern Environmental History. New York: Cambridge University Press, 1989, p.289-307.

WORSTER, D. Para fazer história ambiental. Estudos Históricos. Vol.4, $\mathrm{n}^{\circ} 8$, p.198-215, 1991.

ZIMMERMANN, B e WERNER, M. Pensar a História Cruzada: entre empiria e reflexividade, Textos de História, vol.11, nº 1-2, 2003, p.83-127 [original: Annales, jan-fev 2003].

\section{Notas}

\footnotetext{
1 "Disciplina" deriva de discere, palavra latina que remete ao sentido de "aprender". O discípulo (discipulus), expressão igualmente derivada deste verbo, é “aquele que aprende". É importante lembrar ainda que a palavra disciplina também comporta o sentido de normas de comportamento e de conduta que também devem ser aprendidas e observadas. Daí que a palavra reaparece quando usamos o termo no sentido de imposição de um padrão, mas também de adestramento, punição ou controle (é de acordo com esta última acepção que falamos nas "sociedades disciplinares").

${ }^{2}$ Respectivamente, podemos indicar exemplos da produção rousseauniana para cada um destes campos: Emílio ou Da Educação (1762), Cronologia Universal ou história desde os tempos da criação até o presente (1731), Do Contrato Social (1762), Considerações sobre o Governo da Polônia (1771), Discurso sobre a Economia Política (1755), Ensaio sobre a Origem das Línguas (1759), Cartas Elementares sobre a Botânica (1772), Dicionário de Música (1767), Discurso sobre a origem e os fundamentos da Desigualdade entre os homens (1753). Para uma visão mais geral sobre Rousseau, ver CASSIRER, 2012;

${ }^{3}$ Além da ópera Le Devin du Village (1752), Rousseau também compôs o ballet Les Muses Galantes (1743), e o libreto para o melodrama Pygmalion (1762), com música de Horace Coignet (1735-1821). Os textos sobre Música, além do já citado Dicionário de Música (1767), também estão presentes no conjunto de obras do filósofo, como é o caso da Dissertação sobre a Música Moderna, publicada em 1743. Para uma compreensão do Rousseau Músico, ver STRAUSS, 1978.

${ }^{4}$ Inter, como se sabe - e conforme será discutido mais adiante em um âmbito maior de implicações - é um prefixo que se refere à ação recíproca entre dois aspectos, elementos ou campos. Neste caso, não se trata somente de A agir sobre B, mas de B, concomitantemente, também agir sobre A. Rigorosamente falando, para se ter interdisciplinaridade é preciso que se deixe agir uma disciplina sobre a outra, e viceversa (ou um campo de saber sobre o outro). Muitos dos filósofos iluministas, de certo modo, promoviam
} 
essa ação recíproca entre os saberes. Esta é uma questão a ser investigada, futuramente, em maior profundidade.

${ }^{5}$ Voltaire escreveu obras literárias e teatrais, ao mesmo tempo em que produzia ensaios filosóficos e antropológicos, textos políticos ou obras historiográficas. Montesquieu interessou-se tanto pelas ciências naturais como pelos estudos sociais, jurídicos e históricos. David Hume escreveu sobre filosofia, ética, metodologia científica e história, além de explorar temas que hoje seriam enquadrados no âmbito sociológico.

${ }^{6}$ A aproximação entre as expressões "pluri" e "multi" disciplinar como termos que não faz muito sentido distinguir, ao menos do ponto de vista de sua origem etimológica, é proposta, por exemplo, por Olga Pombo (2008: 13). Já Hilton Japiassu prefere nuançar as duas expressões: a ideia de agrupamento apareceria em ambos os casos - o multi e o pluridisciplinar - mas somente neste último surge decisivamente a preocupação de agrupar as disciplinas de modo a "fazer aparecer as relações entre elas" (JAPIASSU, 1976:73-74).

${ }^{7}$ Alguns autores atribuem à ideia de multidisciplinaridade, de fato, o mero convívio justaposto de disciplinas. Julie Thompson Klein, por exemplo, considera que a natureza do multidisciplinar é "essencialmente aditiva, e não integrativa" (KLEIN, 1990, p.56). Para outra obra de Julie Thompson Klein, ver ainda seu ensaio de 1996.

${ }^{8} \mathrm{O}$ mesmo tema da fome também pode ser trabalhado interdisciplinarmente, no sentido estrito que pode ter essa palavra. E isto pode ser feito mesmo que por um único pesquisador. Um exemplo clássico e particularmente notável é o livro Geografia da Fome, de Josué de Castro (1946), o qual apresenta um estudo que entrelaça a geografia, história, antropologia, economia, nutrição, medicina e outros saberes. Produz-se aqui um novo saber, claramente múltiplo e complexo. Além disso, o próprio autor transformase através deste estudo. Como classificá-lo a partir daqui? Geógrafo, médico, nutricionista, antropólogo, historiador?

${ }^{9}$ É o mesmo espírito que encontramos em outros prefixos gregos, como "tra", "trás", "ter", os quais podemos encontrar em palavras como "traduzir", "traspassar", "tresloucado".

${ }^{10}$ Em Latim, transitus é o particípio passado de transire, que corresponde a "ir através, cruzar".

${ }^{11}$ Referimo-nos, neste caso, às modalidades da História Cruzada ou da História Interconectada importantes perspectivas historiográficas que se desdobraram da chamada História Comparada. Sobre a História Cruzada, ver ZIMERMANN, 2003: 83-127. Sobre a História Transnacional, ver SEIGEL, 2005: 62-90. Para uma abordagem de História Conectada, ver SUBRAHMANYAM, 2004.

${ }^{12}$ Palavra derivada, a partir do latim, do verbo intervenire, e que significa "vir por dentro", abarcando sentidos como o de "interferir", "intrometer-se", "imiscuir-se".

13 "Interpretar" significa "dar a conhecer por dentro". A palavra é formada pela junção do prefixo inter com o radical prat ("dar a conhecer").

${ }^{14}$ Para evocar divisões, partilhas e diálogos que se estabelecem no interior de uma mesma disciplina, utilizaremos a palavra "intradisciplinaridade", que corresponde à formação de modalidades internas a um mesmo campo de saber. Assim, a Mecânica, Ótica, Astrofísica, Termodinâmica, ao lado de vários outros âmbitos de estudo, correspondem ao espaço intradisciplinar da Física. Na História, podemos falar em História Econômica, História Política, História Cultural, Micro-História, e assim por diante.

${ }^{15}$ Este sentido específico para a palavra disciplina como campo de saber começa a ser empregado desde o período renascentista. Sobre isto, cfe. O ensaio "Disciplina e Interdisciplinaridade" de Heinz Heckhausen, inserido na coletânea POMBO, GUIMARÃES e LEVY, 2006.

${ }^{16} \mathrm{O}$ coroamento da história da elucidação sobre o DNA com o prêmio Nobel de Medicina para James Watson (n.1928) e Francis Crick (1916-2004) também é particularmente interessante, uma vez que a longa história desta descoberta começa em 1860 com o trabalho conjunto desenvolvido pelo médico suíço Friedrich Miescher (1844-1895) e pelo químico alemão Félix Hopper-Seiler (1825-1895). Esta cooperação culminou em 1871 com a identificação da nucléina, que abriu um portal de novas possibilidades. A seguir, outro médico, o histologista Richard Altmann (1852-1900), acrescentou sua própria contribuição, o mesmo se dando com o bioquímico Albrecht Kossel (1853-1927). Os progressos no estudo do DNA, a partir daí, seguiram com importantes contribuições de estudiosos diversos até a época de Watson e Crick, que em 1953 publicaram seu célebre artigo.

${ }^{17}$ Barasab Nicolescu, físico especialista em partículas elementares, notabilizou-se como fundador do Centro Internacional de Pesquisas e Estudos Transdisciplinares (CIRET), e como cofundador do Grupo 
de Pesquisas sobre a Transdisciplinaridade da UNESCO (1992), além de ser autor de um conjunto importante de obras sobre o conhecimento transdisciplinar.

18 Tal perspectiva sobre a Interdisciplinaridade é também reenunciada no Manifesto da Transdisciplinaridade (1997) que também ficou conhecido como A Síntese do Congresso de Locarno, em referência ao congresso mundial que se realizou naquela cidade suíça e se encerrou com a redação deste documento, em 1997. Neste, também é explicitada uma diferenciação entre os âmbitos da multi, inter e transdisciplinaridade.

19 Basicamente, a sofisticada tecnologia utilizada pela Medicina Nuclear - a qual integra interdisciplinarmente a física, a química, a eletrônica, a cibernética e a farmácia - proporciona a possibilidade observar o estado fisiológico dos tecidos de forma não invasiva, através da marcação de moléculas participantes nesses processos fisiológicos com isótopos radioativos.

${ }^{20}$ A expressão História Ambiental, como proposta de um campo de estudos, foi cunhada em 1972 por Robert Nash (1972: 362-377). Para uma mais visão geral acerca dos desenvolvimentos recentes da História Ambiental, cfe. FREITAS, 2007: 21-33; WORSTER, 1991: 198-215; e WORSTER, 1989: 289307. A propósito da formação de novos campos interdisciplinares envolvendo a interação entre o mundo humano e os ambientes naturais, pode-se ainda lembrar o surgimento de um novo campo que foi alternadamente nomeado 'Ecologia da Paisagem' e 'Geoecologia', o qual compartilha alguns objetos e problemas com a História Ambiental. Sobre e Ecologia da Paisagem, ver NAVEH, 2000: 7-26.

${ }^{21}$ Expressão utilizada por CIURANA, 2003: 58.

${ }^{22}$ CIURANA, 2003: 58.

${ }^{23}$ Para empreender uma História do Clima, Le Roy Ladurie precisou mobilizar conhecimentos ligados não só à Meteorologia, como também à Biologia, à Botânica, e a outras ciências.

${ }^{24} \mathrm{Ou}$ os pensadores que viveram em uma época mais flexível e de menor isolamento disciplinar.

${ }^{25}$ CASTILLO, 1987: 153.

${ }^{26}$ A Teoria dos Sentimentos Morais (1759), de Adam Smith, foi escrita dezessete anos da Investigação sobre a Natureza e a Causa da Riqueza das Nações (1776).

${ }^{27}$ A formação universitária de Adam Smith deu-se na área de filosofia social, na Universidade de Glasgow.

${ }^{28}$ Traité médico-philosophique sur l'aliénation mentale ou La manie (1801). Neste tratado, Pinel já procede a uma classificação e divisão dos diversos casos que eram vistos como loucura em categorias próprias, como as manias, melancolias, demências e idiotias.

${ }^{29}$ O pioneiro do movimento manicomial - negador da tradicional psiquiatria de reclusão - foi o médico veneziano Franco Basaglia (1924-1980). Ao lado disso, já desde os anos 1960 vinham se desenvolvendo, a partir das contribuições de David Cooper e Ronald Laing, as propostas da chamada Anti-Psiquiatria.

${ }^{30}$ Richard Wagner (1813-1883), compositor alemão de óperas, preconizava com os seus dramas musicais a conjugação, em uma obra de arte total, da música, teatro, canto, dança e artes plásticas.

${ }^{31}$ Kandinsky também escreveu poemas extremamente inovadores que fazem referência a cores e linhas; deste modo, pode-se dizer que, com esta parte de sua produção artística, Kandinsky investiu na possibilidade de imaginar e sentir pictoricamente a Poesia.

${ }^{32}$ LÉVIS-STRAUSS, 2010: 157.

${ }^{33}$ A proposta de Kandinsky era a de criar a "pintura pura", a qual deveria ter a mesma capacidade apresentada pela Música de gerar respostas emocionais nos ouvintes, sem que fosse preciso aludir a qualquer elemento figurativo ou literário. As concepções do pintor sobre a possível musicalidade da pintura podem ser encontradas no livro escrito por ele mesmo: Do Espiritual em Arte (1912). Há ainda um texto mais específico escrito pelo pintor: Pintura como uma Arte Pura (1913).

${ }^{34} \mathrm{Um}$ amplo estudo sobre as relações interartísticas entre Pintura e Música, e também sobre as correspondências possíveis entre as histórias de cada uma destas formas artísticas de expressão, foi realizado em 1998 pelo musicólogo francês François Sabatier (n.1945), com o livro Mirois de la Musique (1998).

${ }^{35}$ Os architektons - maquetes arquitetônicas brancas, constituídas pelas montagens interligadas de cubos, prismas e cilindros - foram exibidos em março de 1926, em Varsóvia.

${ }^{36}$ Os penetráveis, de Hélio Oiticica, eram espaços em forma de labirinto nos quais o espectador podia entrar para usufruir, além da experiência visual e performativa proporcionada, de experiências sensoriais 
também relacionadas ao tato, olfato, audição, ou mesmo paladar. Eram obras de arte interativas, que precisavam ser vivenciadas pelos espectadores. Rompia-se o limite, portanto, entre o artista e o público, ou entre a obra de arte e o próprio mundo.

${ }^{37}$ Um exemplo típico de arte conceitual é a obra idealizada por Joseph Kosuth (n.1945) com o título Uma e Três Cadeiras (1969), na qual são colocadas lado a lado uma cadeira (um objeto), uma fotografia desta, e uma definição de dicionário para "cadeira", em uma folha de papel. Kosuth idealizou uma série de obras como esta, cuja finalidade é rediscutir os próprios limites da Arte, ou a sua superação.

${ }^{38}$ A Fotografia, no Cinema (que deve ser diferenciada da tradicional arte da Fotografia que trabalha com imagens estáticas), é responsável por inúmeros aspectos: a angulação conforme a câmera focaliza o objeto em cena, a iluminação, o enquadramento, os contrastes, os tipos de lentes utilizadas, as cores e tons da imagem. Cada um destes aspectos, que compõem a Fotografia como um todo, pode envolver diferentes operadores e profissionais.

${ }^{39}$ Frase cunhada por Glauber Rocha (1939-1981) para explicitar o espírito do Cinema Novo. Na prática, não era bem assim, pois os filmes produzidos por este movimento continuaram a ser produções coletivas e, certamente, interartísticas e interdisciplinares. De todo modo, hoje a tecnologia digital e a Internet proporcionam a possibilidade de indivíduos isolados produzirem vídeos para serem disponibilizados em sites como o youtube. Distanciamo-nos, aqui, do caráter coletivo e interdisciplinar do Cinema. 